\title{
High Heat Producing Volcano-Plutonic Rocks of the Siner Area, Malani Igneous Suite, Western Rajasthan, India
}

\author{
Laishram Sarjesh Singh, G. Vallinayagam \\ Department of Geology, Kurukshetra University, Kurukshetra, India \\ Email: sarjesh.khuman@gmail.com
}

Received September 3, 2012; revised September 29, 2012; accepted October 29, 2012

\begin{abstract}
The volcano-plutonic rocks of the Siner area of the Malani Igneous Suite (MIS) are characterized by high content of radioactive elements (U, Th, K) and are classified as high heat producing felsic volcano-plutonic rocks of A-type granitoid. Microgranite shows highly comparable heat production (26.07 HP) and total heat generation value (62.06 HGU in average) as compared to other granite $(\mathrm{HP}=12.73$; $\mathrm{HGU}=26.57)$, rhyolite $(\mathrm{HP}=4.98$; $\mathrm{HGU}=11.85)$ and trachyte $(\mathrm{HP}=5.00 ; \mathrm{HGU}=11.91)$. The volcano-plutonic rocks of the present show higher average value of total HGU than the average value of 3.8 HGU for the continental crust, which suggests a possible linear relationship among the crustal heat generation of the MIS.
\end{abstract}

Keywords: Radioactivity; Volcano-Plutonic Rocks; Malani Igneous Suite

\section{Introduction}

The presence of radioactive elements $(\mathrm{U}, \mathrm{Th}, \mathrm{K})$ in the earth crust and plays a role in continental heat flow. Their content are significant in understanding the nature of the source rocks. The geochemistry of $U$ and Th has been studied in many granitoids from different areas by large number of worker on radioactive heat generation [1-11]. The rocks of the Siner and its adjoining areas are characterized by high concentrations in $\mathrm{SiO}_{2}, \mathrm{Na}_{2} \mathrm{O}, \mathrm{K}_{2} \mathrm{O}$, $\mathrm{Zr}, \mathrm{Nb}, \mathrm{Y}$ and REE (except Eu) but low in $\mathrm{MgO}, \mathrm{Fe}_{2} \mathrm{O}_{3}(\mathrm{t})$, $\mathrm{CaO}, \mathrm{Cr}, \mathrm{Ni}, \mathrm{Sr}$; showing their A-type affinity [12-16]. This paper describes distribution of the volcano plutonic rocks of the Siner area, Malani Igneous Suite, western Rajasthan and their radioactive heat generation characteristics.

\section{Regional Geology and Petrography}

The magmatic rocks of the MIS are spread out in an area about $55,000 \mathrm{~km}^{2}$ in the Indian subcontinent around Tosham in Haryana, Jhunjhunu, Siwana, Jalore, Barmer, Pali, Jaisalmer in Rajasthan and Kirana Hill, Nagar Pakar in Pakistan. The Siner area dominantly consists of felsic volcano-plutonic rocks in the southwestern part of the Siwana Ring Complex occur in the Siner area (Figure 1). Volcano-plutonic associations of the MIS belongs to three different phase. First phase is initiated by flow of minor basic volcanic rocks followed by major felsic flows; second phase is represented by intrusive phase. The dyke rock represents the third phase and they have intruded in the earlier phases.

The Siner granites show hypidiomorphic and equigranular textures and mainly comprise of alkali feldspar (perthite, orthoclase), quartz and alkali amphibole and accessory minerals like sphene, rutile, hematite and magnetite (Figure 2(a)). Principal minerals vary from a few $\mathrm{mm}$ to several $\mathrm{mm}$. orthoclase is subhedral and medium grained and exhibits typical Carlsbad twining (Figure 2(b)). Arfvedsonite and riebeckite occur as prismatic, subhedral crystals. Arfvedsonite represents the principal ferromagnesian mineral. Microgranites in the Siner area are fine to medium grained and they have mineralogical constituents with the granites except for being fine grained (Figure 2(c)).

Rhyolite shows varied colours, is porphyritic as well as nonporphyritic. The porphyritic rhyolites are showing granophyric and flow textures. Phenocrysts of feldspar are mostly rectangular are embedded in aphanitic groundmass of quartz and ferromagnesians minerals. Spherulitic textures are observed in the nonporphyritic rhyolite in which the groundmass consist aggregates of quartz, alkali feldspar, blue colour amphibole (riebeckite, arfvedsonite), magnetite and hematite (Figure 2(d)).

Trachyte shows porphyritic texture comprising alkali feldspar, quartz, plagioclase, alkali amphiboles as essential minerals and magnetite (black) and hematite (brown) as accessory minerals (Figure 2(f)). Plagioclase feldspar occurs as euhedral crystals in quartzofeldspathic groundmass of trachytes. 


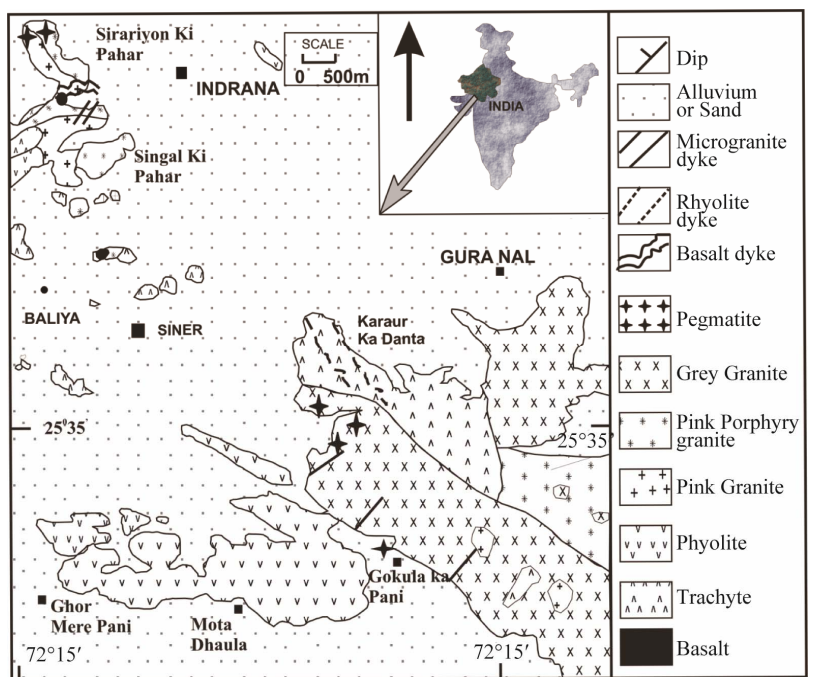

Figure 1. Geological map of the siner and its surrounding of malani igneous suite, western Rajasthan.
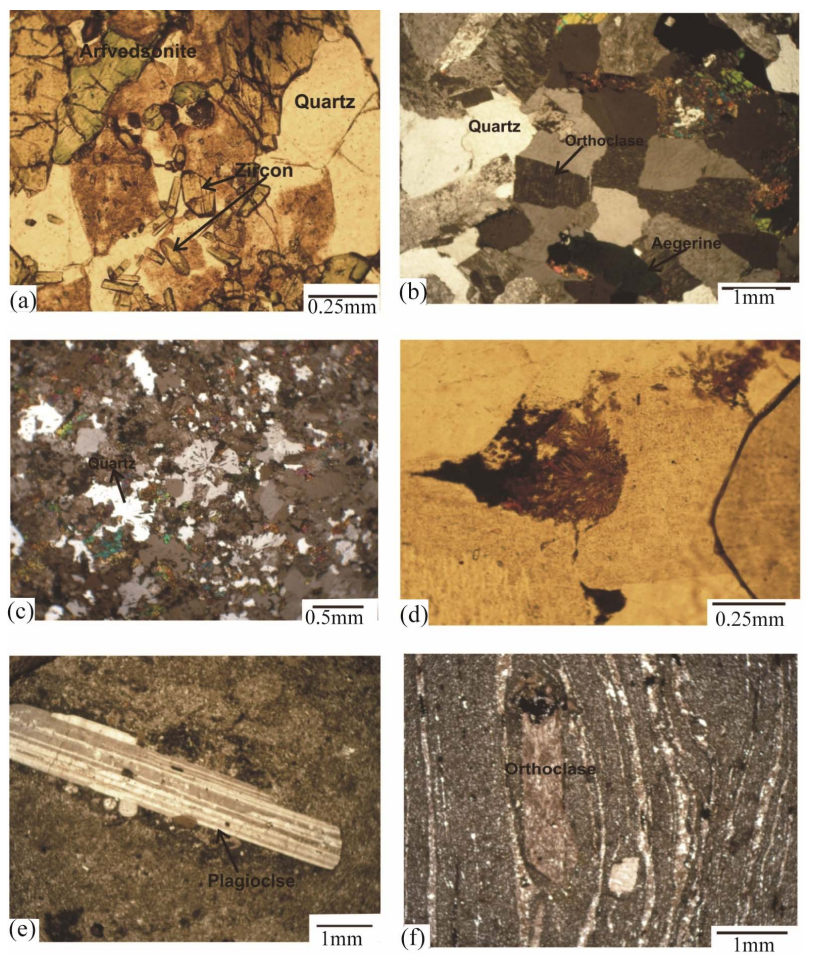

Figure 2. (a) Granite showing hypidiomorphic with crystals of zircon; (b) Equigranular texture of quartz and orthoclase in granite; (c) Hypidiomorphic texture of microgranite; (d) Spherulitic texture shown by rhyolite; (e) Flow structure with porphyry plagioclase in rhyolite; (f) Porphyry orthoclase showing trachytic texture.

\section{Geochemistry and Radioactive Heat Generation}

The abundances of radioelements viz. $\mathrm{U}$, Th and $\mathrm{K}$ in the felsic volcano-plutonic were determined by ICP-MS (Perkin Elmer Sciex ELAN DRC-II) at the National
Geophysical Research Institute (NGRI), Hyderabad and X-Ray Fluorescence spectrometer (Bruker S8 TIGER) at the Wadia Institute of Himalayan Geology (WIHG), Dehra Dun (Table 1). Sample dissolution procedures and other analytical details as practiced in these laboratories including analytical accuracy and precision are described in earlier publication $[17,18]$.

The felsic volcano-plutonic rocks of the Siwana Igneous Complex including those of Siner area have been shown to be crustal origin $[15,16,19]$. The rocks in the Siner area are characterized by high $\mathrm{SiO}_{2}$ (up to 72.65 wt\%) and $\mathrm{K}_{2} \mathrm{O}$, and low levels of $\mathrm{CaO}, \mathrm{MgO}, \mathrm{P}_{2} \mathrm{O}_{5}$, $\mathrm{Fe}_{2} \mathrm{O}_{3}$ and $\mathrm{Al}_{2} \mathrm{O}_{3}$. They show high alkali content and $\mathrm{K}_{2} \mathrm{O} / \mathrm{Na}_{2} \mathrm{O}$ ratios. Both felsic volcanic and plutonic rocks of the Siner area generally have high abundance of $\mathrm{Fe}_{2} \mathrm{O}_{3}$, $\mathrm{Na}_{2} \mathrm{O}+\mathrm{K}_{2} \mathrm{O}, \mathrm{Rb}, \mathrm{Zr}, \mathrm{Hf}$, Th, U, Nb, Ta, Y, REE, high HFSE, high $\mathrm{Ga} / \mathrm{Al}, \mathrm{Rb} / \mathrm{Sr}, \mathrm{Zr} / \mathrm{Rb}$ ratios and negative $\mathrm{Eu}$ anomalies.

The Heat Generation Unit (HGU) value and Heat Production (HP) value were computed from the measured abundance of $\mathrm{U}$, Th and $\mathrm{K}$ using the relation given by Birch, ${ }^{1}: \mathrm{A}\left(\mu \cdot \mathrm{Wm}^{-3}\right)=0.01 \times \rho(9.69 \mathrm{Cu}+3.58 \mathrm{Ck}+$ $2.65 \mathrm{Cth}$ ), where $\mathrm{A}$ is heat production and $\rho$ is density in $\mathrm{gm} / \mathrm{cm}^{-3}$ which is $2.7 \mathrm{gm} / \mathrm{cm}^{-3}$ for granites and felsic volcanic rocks [1]. The $\mathrm{Cu}$ and $\mathrm{Cth}$ are concentration of $\mathrm{U}$ and $\mathrm{Th}$ in ppm respectively whereas $\mathrm{Ck}$ is concentration of $\mathrm{K}$ in $\mathrm{wt} \%$. The heat production $\left(\mu \cdot \mathrm{Wm}^{-3}\right)$ unit may be converted into heat generation unit $\left(1 \mathrm{HGU}=10^{-3}\right.$ $\mathrm{cal} \cdot \mathrm{cm}^{-3} \cdot \mathrm{sec}^{-1}$ ) using the value of $1 \mathrm{HGU}=0.42 \mu \cdot \mathrm{Wm}^{-3}$ obtained for the Gansboden granite gneiss at the $\mathrm{Gu}-$ spisbach heat flow site of Central Alps of Switzerland [3]. The radio element concentration (Ur) is calculated as radioelement $U r$ equivalents: $1 \mathrm{ppm}$ of $\mathrm{U}$ in equilibrium $(1 \mathrm{ppm} \mathrm{eU})=1 \mathrm{Ur} ; 1 \mathrm{ppm}$ of Th in equilibrium $(1 \mathrm{ppm}$ eTh) $=0.5 \mathrm{Ur} ; 1 \mathrm{wt} \%$ of $\mathrm{K}=2 \mathrm{Ur}^{6}$.

The radioelement data shows that the felsic dyke rocks (microgranite) samples have higher concentration of $U$ (32.29 - $98.71 \mathrm{ppm})$ and Th (23.26 - $216.8 \mathrm{ppm})$ than the granite $(\mathrm{U}=3.15-86.11 \mathrm{ppm}$; $\mathrm{Th}=21.99-152.97 \mathrm{ppm})$, rhyolite $(\mathrm{U}=2.91-18.10 \mathrm{ppm}$; $\mathrm{Th}=1.54-97.66 \mathrm{ppm})$ and trachyte $(\mathrm{U}=5.92-12.01 \mathrm{ppm}$; Th $=21.93-62.21$ $\mathrm{ppm}$ ). The felsic dyke rocks (microgranites) have the highest values of Ur vary from 51.06 to 214.11 as compared to granites (24.26 - 68.26), rhyolite (11.64 - 74.15) and trachyte (20.85 - 48.89). The $U$ and Th concentrations in granites are significantly (20 - 8 times) higher than the world average concentration of $\mathrm{U}(4 \mathrm{ppm})$ and Th (18 ppm) in granite [2]. The distribution of $U$ and Th for granites, microgranites, rhyolite and trachytes are showing positive correlation in the Th-U diagram. The enrichment of $U$ in granites and felsic volcanic rocks appear to be fractional differentiation which also indicates increase of $\mathrm{K}$. The $\mathrm{Th} / \mathrm{U}$ ratios of the Siner area volcano-plutonic rocks are comparable and fairly close to 
Table 1. Radioelements, heat production and radioactive heat generation data of the Siner area, Malani igneous suite, western Rajasthan.

\begin{tabular}{|c|c|c|c|c|c|c|c|c|c|c|}
\hline \multirow{2}{*}{ Sample } & \multirow{2}{*}{$\begin{array}{c}\mathbf{U} \\
(\mathrm{ppm})\end{array}$} & \multirow{2}{*}{$\begin{array}{c}\text { Th } \\
(\mathrm{ppm})\end{array}$} & \multirow{2}{*}{$\begin{array}{c}\mathbf{K} \\
(\%) \\
\end{array}$} & \multirow{2}{*}{$\mathbf{T h} / \mathbf{U}$} & \multirow{2}{*}{$\begin{array}{c}\text { HP } \\
\left(\mu \cdot \mathrm{Wm}^{-3}\right)\end{array}$} & \multirow{2}{*}{ Ur } & \multicolumn{3}{|c|}{ Heat generation (in HGU) due to } & \multirow{2}{*}{$\begin{array}{l}\text { Total } \\
\text { HGU }\end{array}$} \\
\hline & & & & & & & $\mathbf{U}$ & Th & $\mathbf{K}$ & \\
\hline \multicolumn{11}{|c|}{ Granite } \\
\hline D8 & 3.15 & 25.94 & 4.07 & 8.23 & 3.07 & 24.26 & 1.96 & 4.42 & 0.94 & 7.32 \\
\hline S2 & 24.7 & 105.44 & 3.95 & 4.27 & 14.39 & 85.32 & 15.39 & 17.96 & 0.91 & 34.26 \\
\hline S3 & 46.71 & 152.97 & 4.1 & 3.27 & 23.56 & 131.395 & 29.10 & 26.06 & 0.94 & 56.10 \\
\hline S8 & 11.33 & 41.93 & 4.1 & 3.70 & 6.36 & 40.495 & 7.06 & 7.14 & 0.94 & 15.14 \\
\hline S16 & 19.52 & 44.44 & 4.05 & 2.28 & 8.68 & 49.84 & 12.16 & 7.57 & 0.93 & 20.66 \\
\hline $\mathrm{S} 21$ & 86.11 & 148.1 & 4.05 & 1.72 & 33.52 & 168.26 & 53.64 & 25.23 & 0.93 & 79.80 \\
\hline S24 & 15.36 & 60.81 & 3.85 & 3.96 & 8.74 & 53.465 & 9.57 & 10.36 & 0.89 & 20.81 \\
\hline GRNL & 6.02 & 21.99 & 4.3 & 3.65 & 3.56 & 25.615 & 3.75 & 3.75 & 0.99 & 8.49 \\
\hline \multicolumn{11}{|c|}{ Microgranite dyke } \\
\hline S7 & 98.71 & 216.8 & 3.5 & 2.20 & 41.68 & 214.11 & 61.49 & 36.93 & 0.81 & 99.23 \\
\hline $\mathrm{S} 14$ & 32.29 & 23.26 & 3.57 & 0.72 & 10.46 & 51.06 & 20.11 & 3.96 & 0.82 & 24.90 \\
\hline \multicolumn{11}{|c|}{ Rhyolite } \\
\hline $\mathrm{F} 1$ & 8.13 & 32.05 & 4.22 & 3.94 & 4.83 & 32.595 & 5.06 & 5.46 & 0.97 & 11.50 \\
\hline $\mathrm{F} 2$ & 4.52 & 31.05 & 3.76 & 6.87 & 3.77 & 27.565 & 2.82 & 5.29 & 0.87 & 8.97 \\
\hline $\mathrm{F} 4$ & 18.1 & 97.66 & 3.61 & 5.40 & 12.07 & 74.15 & 11.28 & 16.64 & 0.83 & 28.74 \\
\hline S9 & 2.91 & 1.54 & 3.98 & 0.53 & 1.26 & 11.64 & 1.81 & 0.26 & 0.92 & 2.99 \\
\hline S30 & 5.99 & 28.04 & 2.49 & 4.68 & 3.81 & 24.99 & 3.73 & 4.78 & 0.57 & 9.08 \\
\hline S43 & 4.93 & 34.71 & 3.77 & 7.04 & 4.14 & 29.825 & 3.07 & 5.91 & 0.87 & 9.85 \\
\hline \multicolumn{11}{|c|}{ Trachyte } \\
\hline $\mathrm{S} 28$ & 5.92 & 26.43 & 0.86 & 4.46 & 3.52 & 20.855 & 3.69 & 4.50 & 0.20 & 8.39 \\
\hline $\mathrm{S} 48$ & 6.21 & 21.93 & 4.4 & 3.53 & 3.62 & 25.975 & 3.87 & 3.74 & 1.01 & 8.62 \\
\hline S37 & 12.01 & 62.21 & 2.89 & 5.18 & 7.87 & 48.895 & 7.48 & 10.60 & 0.67 & 18.74 \\
\hline
\end{tabular}

HP: Heat production; Ur: Radioelement concentration; HGU: Heat generation unit.

the upper crustal estimate of 3.8 (Figure 3(a)) [20].

In K-U-Th diagram (Figure 3(b)) of the volcanic and plutonic rocks plot near Th apex, indicating high content of Th (up to $216.80 \mathrm{ppm}$ ) in the samples, and hence the heat generation of Th (3.74 - $36.93 \mathrm{HGU})$ is much higher than U (1.96 - 61.49 HGU) and K (0.20 - 1.01 HGU).

The average total heat generation value of the felsic volcanic (21 HGU) and plutonic rocks (30 HGU) of the study area are much higher than the average value of 3.8 HGU for the continental crust. These volcano-plutonic rocks of the Siner area also also have higher values than the average value of 14.21 HGU obtained from the Kundal volcano-plutonic rocks in the MIS [10] and 8.3 HGU from the Peninsular India [21]. Volcanic and plutonic rocks of the Siner area of MIS shows higher concentration of $\mathrm{U}$ and Th as compared to A-type granite and rhyolite of the Northwestern Ontario [22] and A-type rhyolite of the St. Francois Mountains, Missouri [23] (Figure 3(c)). The Siner granite samples have the average highest heat productivity value $\left(12.73 \mu \cdot \mathrm{Wm}^{-3}\right)$ closely similar to that of the Jhunjhunu granites of MIS $\left(12.06 \mu \cdot \mathrm{Wm}^{-3}\right)$ [9] and A-type Nigerian younger granites $\left(11.16 \mu \cdot \mathrm{Wm}^{-3}\right)$ [24]. The Ur vs HP diagram (Figure 3(d)) show that the Siner volcanic rocks are in a linear pattern with the Mokalsar rhyolite [8] and Jhunjhunu rhyolite of MIS [9]. Granites with inferred heat production value more than 7 HGU are classified as High Heat Producing (HHP) granitoids and "hot crust" category [10]. In this study the granites and other felsic volcanics with heat production values are more than $5 \mu \cdot \mathrm{Wm}^{-3}$, ranging between $2-20$ $\mu \cdot \mathrm{Wm}^{-3}$. This radioactive heat generation data present here also suggest a possible linear relationship between the surface heat flow and crustal heat generation in the MIS.

\section{Conclusion}

The volcano plutonic rocks of the Siner area are characterized by high content of $\mathrm{SiO}_{2}, \mathrm{Na}_{2} \mathrm{O}+\mathrm{K}_{2} \mathrm{O}, \mathrm{Nb}, \mathrm{Y}$, $\mathrm{Ta}, \mathrm{Zr}, \mathrm{Hf}, \mathrm{Ga}, \mathrm{U}$, Th, REE and low content of MgO, 


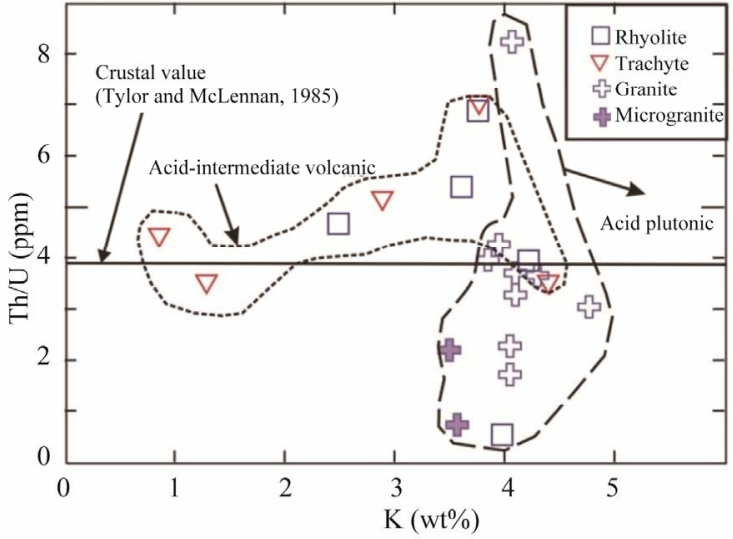

(a)

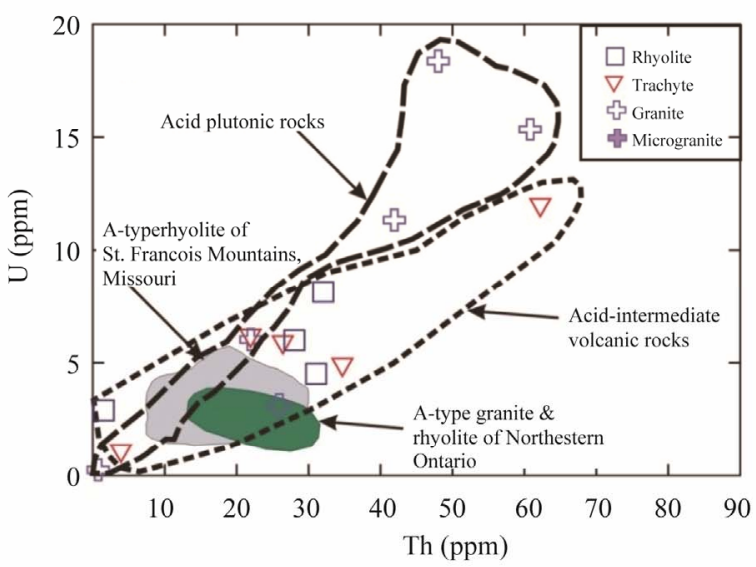

(c)

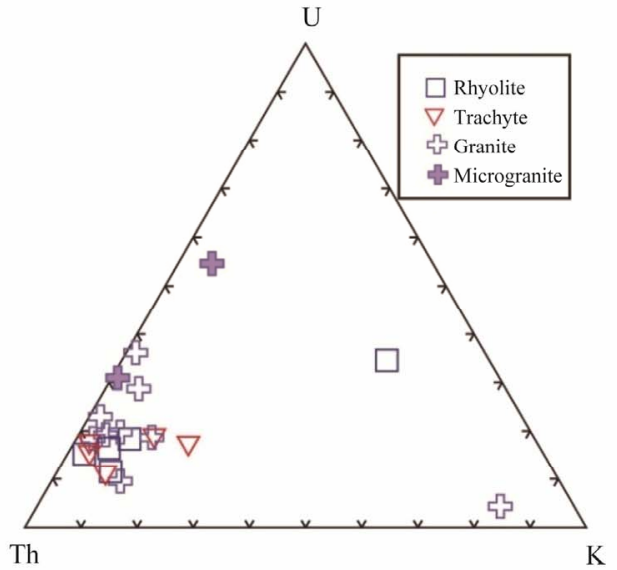

(b)

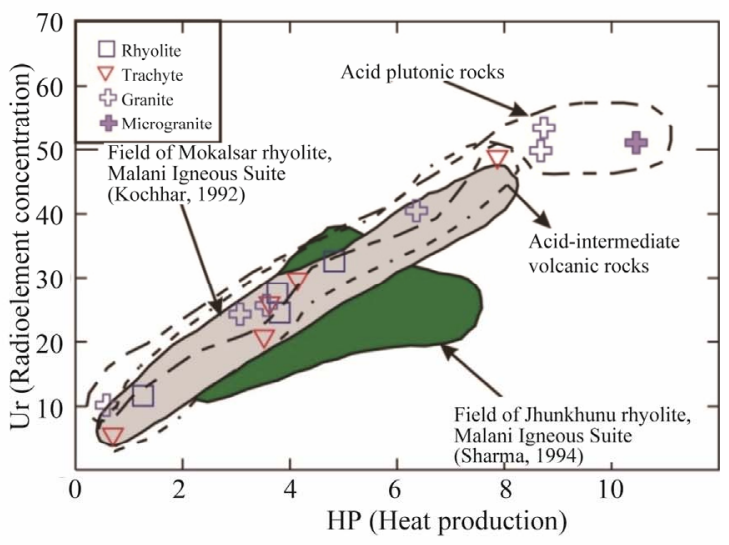

(d)

Figure 3. (a) Th/U vs K plot for the volcano-plutonic rocks of the Siner; (b) Th-U-K for the volcano-plutonic rocks of the Siner; (c) U vs Th plot of the Siner volcano-plutonic rocks; (d) Ur vs HP for the volcano-plutonic rocks of the Siner.

$\mathrm{CaO}$ and $\mathrm{Al}_{2} \mathrm{O}_{3}$. The average distribution of total heat generation in (62.06 HGU), granite ( $\mathrm{HGU}=26.57)$, rhyolite (HGU $=11.85)$ and trachyte $(\mathrm{HGU}=11.91)$ of the Siner area are much higher than the average value of 3.8 HGU of the continental crust and 8.3 HGU obtained from Peninsular India and classified as "hot crust". Hence they are high heat producing crustal rocks which suggest a possible linear relationship among the crustal heat generation of MIS and according to the geochemistry data they are formed by low degree anatexis of crustal material.

\section{Acknowledgements}

The first author wishes to acknowledge the financial support of the University Research Scholarship, Kurukshetra University, Kurukshetra to carry out the research work. The authors wish to express their thanks to Dr. V. Balaram, Dr. M. Satyanarayanan, National Geophysical Research Institute, Hyderabad and Dr. N. K. Saini, Wadia Institute of Himalayan Geology, Dehra Dun for chemical analyses.

\section{REFERENCES}

[1] F. Birch, "Heat from Radioactivity,” John Wiley, New York, 1954, pp. 148-174.

[2] J. J. W. Rogers and J. A. S. Adams, “Thorium,” In: K. H. Wedepohl, Ed., Handbook of Geochemistry, SpringerVerlag, Berlin, 1969, pp. 11-14.

[3] L. Rybach, D. Werner, S. Mueller and G. Berset, "Heat Flow, Heat Production and Crustal Dynamics in the Central Alps, Switzerland,” Tectonophysics, Vol. 41, No. 1-3, 1977, pp. 113-126.

[4] M. Pagel, "The Mineralogy and Geochemistry of Uranium, Thorium and Rare Earth Elements in Two Radioactive Granites of the Vosges, France," Mineralogical Magazine, Vol. 46, No. 339, 1982, pp. 149-161.

[5] J. A. Plant, C. O’Brein, J. Tarney and J. Hurdlet, “Geochemical Criteria for Recognition of High Heat Producing Granites,” In: High Heat Production Granites, Hydrothermal Alteration and Ore Genesis, Institute of Mineralogy and Meteorites, London, 1985, pp. 263-283.

[6] L. D. Ashwal, P. Morgan, S. A. Kelly and G. A. Preicival, "Heat Production in an Archean Crustal Profile and Im- 
plications for Heat Flow and Mobilization of Heat Producing Elements," Earth and Planetary Science Letters, Vol. 85, No. 4, 1987, pp. 439-450.

[7] N. Kochhar, "High Heat Production Granites of the Malani Igneous Suite, N. W Peninsular India,” Industrial Minerals, Vol. 43, 1989, pp. 339-346.

[8] N. Kochhar, "Mineralization Associated with A-Type Malanimagmatism, Northwestern Peninsular India,” In: S. C. Sarkar, Ed., Metallogeny Related to Tectonic of the Proterozoic Mobile Belts, Oxford-IBH, New Delhi, 1992, pp. 209-224.

[9] R. Sharma, "High Heat Production (HHP) Granites of Jhunjhunu Area, Rajasthan, India,” Bulletin of Indian Geologists Association, Vol. 27, 1994, pp. 55-61.

[10] A. K. Singh and G. Vallinayagam, "Radioactive Element Distribution and Rare-Metal Mineralization in Anorogenic Acid Volcano-Plutonic Rocks of the Neoproterozoic Malani Felsic Province, Western Peninsular India,” Journal of the Geological Society of India, Vol. 73, 2009, pp. 837-853.

[11] G. Vallinayagam and L. G. Singh, "Radioactive Heat Producing Felsic to Intermediate Volcano-Plutonic Rocks of Dhiran Area, Malani Igneous Suite, Western India,” Indian Journal of Earth Sciences, Vol. 4, No. 2, 2011, pp. 68-97.

[12] H. S. Pareek, "Petrochemistry and Petrogenesis of the Malani Igneous Suite, India,” Geological Society of America Bulletin, Vol. 92, 1981, pp. 206-273.

[13] N. Kochhar, "Malani Igneous Suite: Hot-Spot Magmatism and Cratonization of the Northern Part of the Indian Shield," Journal of the Geological Society of India, Vol. 25, 1984, pp. 155-161.

[14] S. K. Bhushan and V. Chandrasekaran, "Geology and Geochemistry of the Magmatic Rocks of the Malani Igneous Suite and Tertiary Alkaline Province of Western Rajasthan," Memoirs of the Geological Survey of India, Vol. 126, 2002, pp. 1-129.

[15] G. Vallinayagam, "Peralkaline-Peraluminous A-Type Rhyolites, Siwana Ring Complex, Northwestern India: Petrogeneticmodelling and Tectonic Implications,” Journal of the Geological Society of India, Vol. 64, 2004, pp. 336-344.

[16] A. K. Singh, R. K. B. Singh and G. Vallinayagam, “Anorogenic Acid Volcanic Rocks in the Kundal Area of the
Malani Igneous Suite. Northwestern India: Geochemical and Petrogenetic Studies," Journal of Asian Earth Sciences, Vol. 27, No. 4, 2006, pp. 544-557.

[17] N. K. Saini, P. K. Mukherjee, M. S. Rathi, P. P. Khanna and K. K. Purohit, "A New Geochemical Reference Sample of Granite (DH-G) from Dalhousie Himachal Himalaya,” Journal of the Geological Society of India, Vol. 52, No. 11, 1998, pp. 603-606.

[18] P. Roy, V. Balaram, A. Kumar, M. Satyanarayanan and T. Gnaeshwar Rao, "New REE and Trace Element Data on Two Kimberlite Reference Materials by ICP-MS,” Geostandards and Geoanalytical Research, Vol. 31, No. 3, 2007, pp. 261-273.

[19] G. Vallinayagam and N. Kochhar, "Geochemical Characterization and Petrogenesis of A-Type, Granites and the Associated Acid Volcanics of the Siwana Ring Complex, Northern Peninsular, India,” In: B. S. Paliwal, Ed., The Indian Precambrian, Scientific Publishers, Jodhpur, 1998, pp. 460-481.

[20] S. R. Taylor and S. M. McLennan, The Continental Crust: Its Composition and Evolution, Black-well Scientific publications, Oxford, 1985.

[21] R. Dhana Raju, J. P. Singh and T. K. Bhattacharya, “A Preliminary Study on Radioactive Heat Generation of Some Precambrian Granitic Rocks of India,” Indian Journal of Earth Sciences, Vol. 10, No. 2, 1983, pp. 112119.

[22] P. Hollings, P. Fralick and S. Kissin, "Geochemistry and Geodynamic Implications of Mesoproterozoic English Bay Granite-Rhyolite Complex, Northwestern Ontario,” Canadian Journal of Earth Sciences, Vol. 41, No. 11, 2004, pp. 1329-1338. doi:10.1139/e04-077

[23] J. F. Menuge, T. S. Brewer and C. M. Seeger, "Petrogenesis of Metaluminous A-Type Rhyolite from the St. Francois Mountains, Missouri and Mesoproterozoic Evolution of the Southern Laurentian Margin,” Precambrian Research, Vol. 113, No. 3, 2002, pp. 269-291. doi:10.1016/S0301-9268(01)00211-X

[24] J. A. Kinnard, R. A. Batchelor, J. E. Whittely and A. B. Mackenzie, "Geochemistry, Mineralization and Hydrothermal Alteration of the Nigerian High Heat Producing," In: High Heat Production (HHP) Granites, Hydrothermal Alteration and Oregenesis, Institute of Mining and Metallurgy, London, 1985, pp. 169-199. 